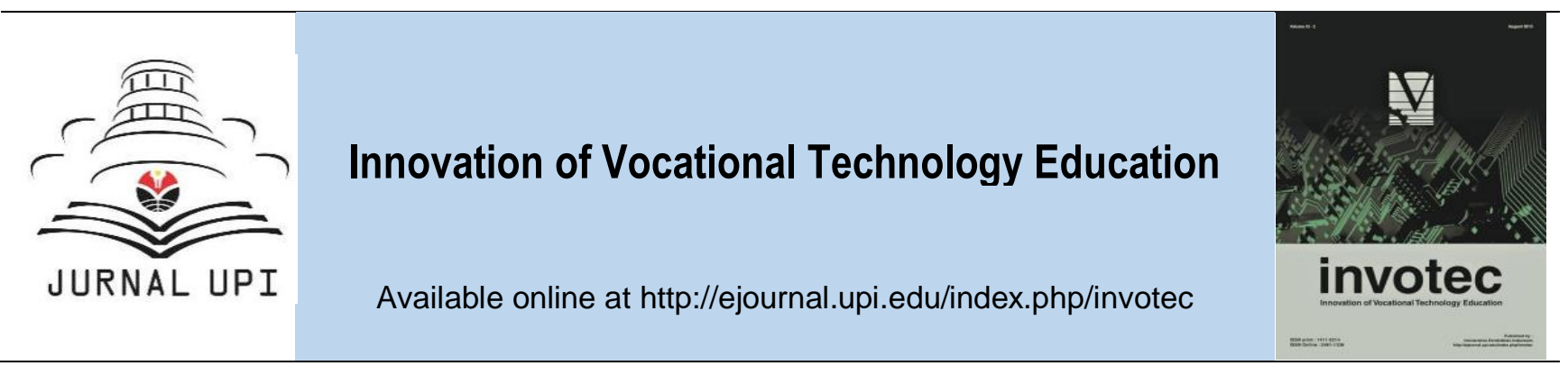

\title{
Innovation Learning: Audio Visual and Outdoor Study to Enhance Student's Understanding of Disaster
}

\author{
M. Hafizul Furqan, Enok Maryani, Mamat Ruhimat \\ Universitas Pendidikan Indonesia, Indonesia
}

\section{ARTICLE INFO}

\author{
A B S T R A C T
}

\section{Article history:}

Received 14 March 2017

Received in revised form 7 April

2017

Accepted 28 April 2017

Available online 31 August 2017

Keywords:

Aceh Tsunami Museum,

Audio visual,

Understanding of disaster

Corresponding author: mhafizulfurqan91@gmail.com
Education is functioned to prepare human to compete in overcoming various challenges. One of challenge faced by Indonesian nation is natural disaster. The effective method to reduce the risk of natural disaster (disaster mitigation) is by enhancing understanding of disaster in each individual. Aceh Tsunami Museum (ATM) is one of important site which is build to remember the big disaster event which happened in 2004 in Aceh and as disaster learning source. This study is aimed to find out the influence of ATM utilization in enhancing students' understanding of disaster, by using outdoor study method (visit ATM) and audio visual media (Film with disaster themed). The research design is Experimental quasi. Sample of this study are students of class X-2 IS and X-3 IS with total of 57 students. Data is obtained from literature study, observation, test, questionnaire, and documentary study. The result showed that utilizing ATM by outdoor study method can better enhance understanding of disaster compared to audio visual media. Constructivism learning approach can create more meaningful learning. Teachers are suggested to apply constructivism learning approach in learning process.

\section{Introduction}

The pattern of learning in curriculum 2013 use constructivism approach in which students construct the knowledge by themselves whereas teacher has a role as facilitator. Learning experience is very important thing. This perspective regard students as center of knowledge information. Minister of Education and Culture Regulation No. 69/2013 about basic framework and curriculum structure of Senior High School/Madrasah Aliyah mentioned that pattern of learning in curriculum 2013 is student-centered in which learning should be interactive (interaction among teacher, student, community, environment, another source/media), learning can be done by network (student can acquire knowledge from whatever sources and from whoever), active learning, team based learning, tool or multimedia based learning and creative learning.

It is expected that teachers as one of important components in learning are able to manage interactive learning. The use of model, media and environment as learning source become the main thing which should be done by teacher. This is as stated by Beavers (2009) teachers are required not 
only to be experts in their content area, but are also expected to be fluent in child psychology, skilled in communication, execute brilliant classroom management strategies, and navigate the unrelenting gauntlet of educational politics. To become professional teachers, they not only master the content of subject but also should be able to manage the class and understand student's psychology.

One function of education is to prepare human who are ready to compete in facing various challenges. One challenge faced by Indonesia nation is natural disaster. Aceh as one of Province in Indonesia has big potency affected by earthquake and tsunami disaster. One big disaster that ever occurred in Aceh is earthquake and tsunami on December $26^{\text {th }} 2004$. The earthquake which occurred at 07.58 a.m. centered in $160 \mathrm{~km}$ of western Aceh cause so many people died. Tejakusuma (2005) stated that the fatalities resulted from Aceh earthquake and tsunami achieve more than 237.448 death whereas totally is estimated not less than 300.000 death. The high numbers of fatalities in a disaster is caused by lack of people's understanding about that disaster. This is as asserted by National Coordination Board for Disaster Management (2007) there are four main factors which can result in fatalities in a disaster namely, lack of understanding toward characteristic of hazard, attitude or behavior which cause the deterioration of natural source quality (vulnerability), lack of information and early warning.

The result caused by those four factors will invoke unpreparedness, helpless and inability to face disaster threat. The effective method to decrease the risk of disaster (disaster mitigation) is by enhancing understanding of disaster in each individual. School as education institution with curriculum as path of knowledge development planning can be functioned as information media which is effective to change the mindset and behavior of society by providing education about mitigation.

ATM is one of important sites which was build after earthquake and tsunami disaster which is functioned to remember that event and as non formal education device about earthquake and tsunami. People had not fully understood the role and function of ATM. This is evident by many visitors who come there just for traveled whereas ATM is also advocated as education device particularly disaster education. The facilities of museum which are adequate can be used by teacher as supporting material in learning activity particularly in material of disaster understanding. The result of observation in ATM shows that there are various facilities which can be used to enhance students' understanding toward disaster, among other: 1) memoriam hall monitor, 2) simulation room, 3) miniature of the fault process occurred 4) monitor of the earthquake process occurred, 5) seismograph, 6) miniature of earth layers, 7) various disaster themed posters, and there are still many other facilities which can be used.

The aims of this study are: to analyze the enhancement of students' understanding of disaster before and after geography learning in experiment class which utilize ATM through outdoor study method. To analyze the enhancement of students' understanding of disaster before and after learning in control class who utilize ATM as learning source through film media. To analyze the enhancement difference of students' understanding of disaster after learning activity between class who use outdoor study method and class who use audio visual media in utilizing ATM as learning source.

Constructivism is psychology and philosophy perspective which view that each individual create or build most of what they learn and understand (Schunk, 2012). Learn constructively had been implemented in Indonesia by the application of 2013 curriculum stated that constructivism learning principle belief that learning and knowledge are created by students themselves and teacher only as facilitator, whereas the nature of knowledge is subjective and personal and is a product of students' cognition-cognition. In learning based on constructivism theory, students' knowledge cannot be transferred from teacher's mind into students' mind. It means that students should be active mentally in building their knowledge structure according to maturity.

Constructive learning theory in its application is strongly related with active learning. School as social institution is a place of social renewal which will be continually developed. Basically, constructivism theory emphasize the forming of cognitive structure and mental process and in each child has that potency based on experience reconstruction occurred in themselves through action/interaction with their environment. Basic difference between cognitive theory and constructivism theory lie on learning aspect scope, in which cognitive theory stated that knowledge (cognitive process) is acquired from child's learning process whereas constructivism theory stated that knowledge (cognitive process) not only acquired from learning process but more than that. Cognitive reconstruction and learning from interaction result from child's environment resulted in new knowledge in child. 
Outdoor study or field study is simply can be defined as study which is held out of class with aimed to bring students directly to see a phenomena. Learning with outdoor study method or field study is learning done by teacher, in which teacher ask students to learn out of class to see the event directly in field used as learning source. The field study relates to students' activities taking place in learning environments outside the traditional (conventional) classroom, such as office environments, historical areas, monuments and museums, national parks, zoos, wetlands, seaside, wild life areas, etc. It is based on the supposition that the most valuable experiences of the students are gained through images taken by the senses (Vassala, 2006).

Outdoor study/field study method can be said as learning process which utilize environment out of lass such as school backyard, museum, zoo, etc and can be used as the supporting learning material for students. Field study learning method can activate students' senses and will give the most fully impression of learning based on Dale's Cone Experience. The goal of learning by using outdoor study method: 1) to provide firsthand experience, 2) to stimulate interest and motivation in science, 3) to add relevance to learning and interrelationships, 4) to strengthen observation and perception skills, and 5) to promote personal (social) development (Behrendt and Teresa, 2014).

Media is various form of channels used by people to deliver message/information which can be utilized to clarify or facilitate students' understanding of certain material or message (Prasetya, 2014). Media are the means for transmitting or delivering messages and in teaching-learning perspective delivering content to learners, to achieve effective instruction (Ahsan dan Akbarn. 2010). Essentially, learning is a communication process, that is process to deliver message in this case is teacher from message source through certain channel or media to receiver in this case is students.

Learning media is one of learning component which give real contribution for the effectiveness and efficiency of learning activity, if that media is suitable and optimal in its use. Media is tool aid in learning activity, as revealed by Ningrum (2015) devices refers to physical equipment used to facilitate the learning process. In addition as tool aid, media appearance in learning activity is functioned to attract attention and grow students' interest so it can develop their learning motivation.

The utilization of media will make the learning process become more active. One of theory reference about media utilization in learning process is Dale's Cone Experience. Dale's Cone experience can be seen from the Figure 1.

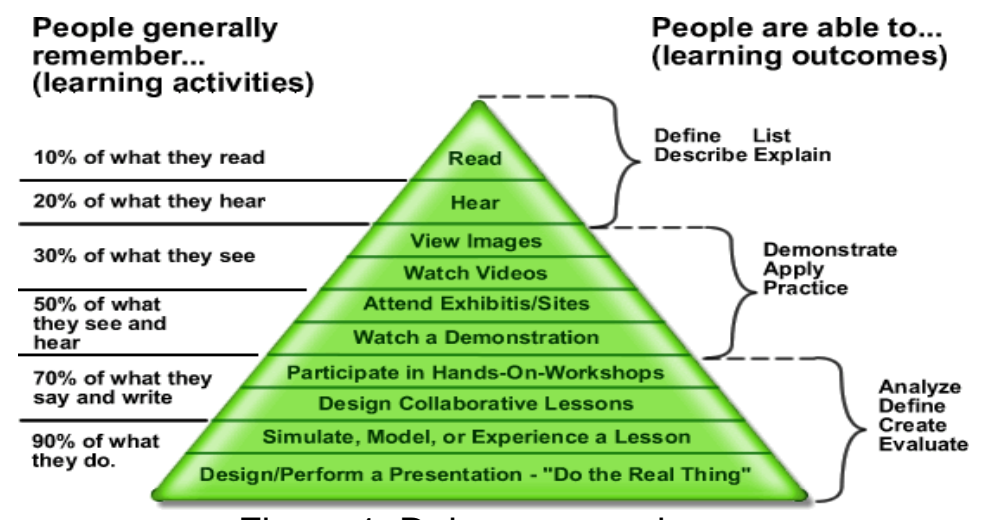

Figure 1. Dale cone exprience

The basic of cone development above is not on difficulty level, but on abstractness level in numbers of kind of senses which are involved when receiving the content of learning or message. Direct experience will give the most fully and most meaningful impression about information and idea contained in this experience.

Museum can be said as non formal educational institution. This is because its function and responsibility in preserving and collecting historical evident which aimed to give understanding and knowledge to people. Museum is permanent body, not depended on who the owner is but should be keep exist (Directorate of Museum, 2007). By visiting the museum, visitors can feel direct experience and learning as exhibited in museum for their life now. The extensive experience obtained from museum covered four aspects: the visit, discussion with museum educators, the development of lesson plans, and practicing teaching in the science museum (Chin, 2004). Utilizing museum will give extensive experience in learning process namely visiting, discussion by utilizing museum facilities, and development of learning kits and its practice in field. 
ATM is a masterpiece of Indonesian' architect named Ridwan Kamil. The idea concept of ATM design adopt local virtue from philosophy of Rumoh Aceh. ATM is build specifically and specially in the central of Banda Aceh city which only distanced $\pm 1 \mathrm{~km}$ from Masjid Raya Baiturahman Banda Aceh. Ridwan Kamil is an architect whose design is legitimated on August $23^{\text {rd }} 2007$ and spend three weeks to do contemplation and small research before deciding to design museum plans which titled Rumoh Aceh as Escape Hill which in the form of staged house as realization of local virtue of Aceh so the museum is designed to become place of rescue if tsunami reoccurred someday (Rahman, 2014). Ridwal Kamil integrate the concepts into life of Aceh people from concept of spirituality in various room corners, one of them is the well of pray in which in the upper side there is word of Allah written in Arabic. Harmonization aspect in social life and community life of Aceh people is realized in the concept of crossed exterior resembling Saman dance. Harmonization in saman dance realize the peace and safe condition in life of Aceh people.

\section{Method}

This study located in SMAN 4 DKI Jakarta Banda Aceh. Sample of study consist of two classes namely class X-1S 3 who use ATM with outdoor study method and class X-IS 2 who use ATM with visual audio media. Instrument of study use test to measure student,s understanding of disaster material. This study use quantitative method with experimental-quasi approach. The pattern of experimental-quasi design used in this study is Randomized Pretest-Posttest Control design.

\section{Result and Discussion}

\subsection{The Enhancement of Disaster Understanding In Study Outdoor Class}

Learning in class by using outdoor study method is done in three times of meetings. In first meeting, researcher help teachers are to administer pretest which contain 40 multiple choice items. In second meeting, teachers and students apply outdoor study method by visiting ATM and in the third meeting teachers distribute worksheet for each group in which each question refer to result of observation toward ATM facility and teacher administer posttest. The test items tested are the same items when doing pretest. Posttest is given to find out how far students' enhancement after using outdoor study method by visiting ATM.

Based on analysis result of G-normalized data, it is obtained interpretation of Gain that are $\mathrm{g}>$ 0.7 of high category with total of 8 students, $0.3 \leq \mathrm{g} \leq$ of medium category with total of 19 students. In experiment class there are no students who get $G$ score with low category. The conclusion obtained from Gain score above is that the use of ATM as disaster learning source give positive influence to students. This can be seen from average score before giving treatment and after giving treatment and increase of Gain score experienced by all students in experiment class. This is in accord with Behrendt and Teresa's statement (2014) that outdoor study method will be effected on: 1) to provide firsthand experience, 2) to stimulate interest and motivation in science, 3) to add relevance to learning and interrelationships, 4) to strengthen observation and perception skills, and 5) to promote personal (social) development.

\subsection{The Enhancement of Disaster Understanding in Audio Visual Media Class}

The learning process use audio visual media by utilizing infocus in classroom and film about ATM by Rahman and added by another video which can represent each sub material in KD 3.7 of disaster adaptation and mitigation. Similar with class with outdoor study method, class with audio visual media is implemented by three times of meetings. Based on analysis of Gain-normalized, there are no students who get high category Gain in control class, whereas 7 students are obtained in medium category Gain of $0.3 \leq \mathrm{g} \leq 0.7$. Whereas 23 students are obtained in low category Gain of $\mathrm{g}<0.3$. This shows that the use of disaster film media and ATM have positive effect toward enhancement of understanding toward disaster even though the average of enhancement is not as high as class who use outdoor study method. 


\subsection{The Enhancement Difference of Disaster Understanding in Outdoor Study Class and Audio Visual Media Class}

The test score change of disaster understanding after treatment is given in experiment class by using outdoor study method is $58 \%$ with high category gain of 0.59 . In control class who use audio visual media, test score of disaster understanding of $31.34 \%$ is obtained with low category gain score of 0.24 . From comparison of posttest in experiment class with outdoor study method and control class with control class who use audio visual method, test result comparison of disaster understanding is obtained as showed in Figure 2.

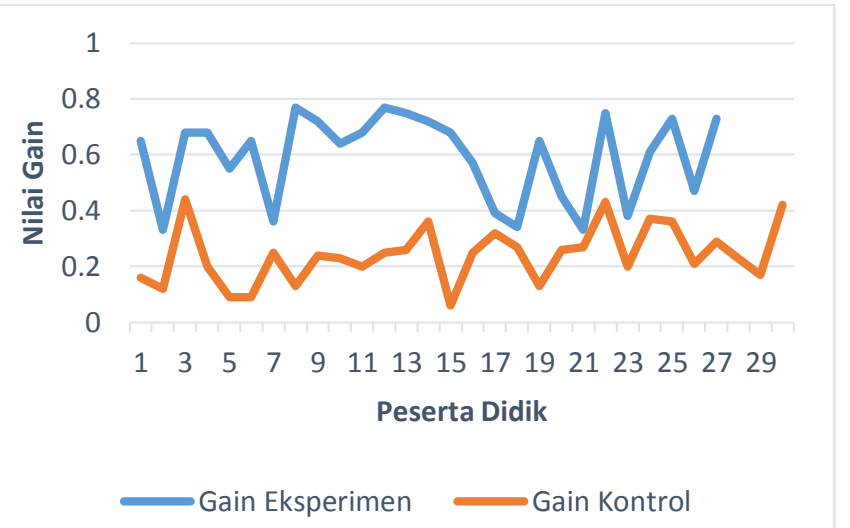

Figure 2. Comparison of disaster understanding

In learning by using constructivism approach, it is mentioned that each individual form or build most of what they learn in which environment play big role in learning process. Basically, constructivism theory emphasize that there is child's potency in formation of cognitive structure and mental process based on reconstruction of experience occur in his/herself through action/interaction with his/her environment (Ahmad, 2014). Before utilizing ATM both with outdoor study method or audio visual method, students have had basic knowledge about disaster particularly earthquake and tsunami. It is because almost of all students are native people who are originated from Aceh and when earthquake and tsunami occurred in 2004 their age were 4-5 years old in average.

Utilizing ATM as learning source is one of efforts to reconstruct and refine the initial knowledge owned by each student. The initial knowledge owned by student can support to reconstruct new knowledge acquired from the use of ATM as learning source. Constructivism support the change and renewal to be occurred which in many things, effected on progress and refinement of view in contextual, dialectical, empirical and information process.

The enhancement difference of disaster understanding between class with outdoor study method and class with audio visual method is resulted caused by using outdoor study method, students can get direct experience which cannot be created in classroom. This prove theory of Dale Cone's Experience that "people will generally remember: $10 \%$ of what they read, $20 \%$ of what they hear, $30 \%$ of what they see and $50 \%$ of what they hear and see". Direct experience will activate students' senses concretely compared to audio visual media which only activate sense of sight and hearing. It can give influence to reception of teaching content or message. The similar thing is also said by Edgar Dale that involving students in direct situation or direct experience which involve the use of all senses will give good effect that is $90 \%$ of memory will be stored in student's memory. It is different with the use of audio visual media which only involve visual and audio sense without giving direct experience in which only $50 \%$ of memory will be stored in student's memory.

Learning by using video has their own strength particularly in time and cost efficiency. Students only sit in classroom to be able to see various events, and the time required also can be adapted in time available. Who argued that the use of media will give effect: (1) save time, (2) increase interest, (3) hold attention, (4) clarify ideas, (5) reinforce concepts, (6) add tone, (7) prove a point, and (8) aid memory. Using video will activate students' visual and audio senses, so they are able to give impression and indirect experience in learning. This will be effected on student's ability to absorb the material which compatible with theory. 


\section{Conclusion}

The conclusion this research are there is enhancement of students' understanding of disaster after learning both in class who use outdoor study method as well as class who use audio visual media by utilizing ATM. There is difference enhancement of students' understanding of disaster after learning between class who use outdoor study method and class who use audio visual media in utilizing ATM as learning source. Class who use outdoor study method is better in enhancing understanding of disaster compared to class who use film media.

\section{REFERENCES}

Ahmad, R. (2014). Pengelolaan Pengajaran. Jakarta: Rineka Cipta.

Ahsan, a. and Akbarn, R.A. 2010. Use of Media for Effective Instruction its Importance: Some Consideration. Journal of Elementary Education a Publication of Dept of Elementary Education IER. University of the Punjab Lahore-Pakistan 18 (1-2). p. 35-40.

Beavers, A. 2009. Teachers As Learners: Implication of Adult Education For Profesional Development. Journal of Collage Teaching \& Learning. 6(7).

Behrendt, M. and Teresa. 2014. A Review of Research on School Field Trips and Their Value in Education. International Journal of Environmental \& Science Education. ISSN 1306-3065.

Chin, C. C. 2004. Museum Exprience-A Resource For Science Teacher Education. International Journal of Science and Mathematics Education 2. p. 63-90. National Science Council, Taiwan. Printed in the Netherlands.

Directorate of Museum. 2007. Pengelolaan Koleksi Museum. Jakarta: Direktorat Jendral Sejarah dan Purbakala.

National Coordination Board for Disaster Management. 2007. Jakarta.

Ningrum, E. 2015. Mendesain Pembelajaran Berbasis Lingkungan Untuk Mengembangkan Kecerdasan Ruang. Prosiding Seminar Nasional Perringatan Hari Bumi Untuk Meningkatkan Kecerdasan Ruang. Bandung: Pendidikan Geografi SPs UPI.

Prasetya, S. P. (2014). Media Pembelajaran Geografi. Surabaya: Ombak

Rahman, A. (2014). Pengembangan Media Audiovisual Museum Tsunami Aceh dalam Framework Knowladge Management. Banda Aceh: Thesis. Unsyiah.

Schunk, D. H. (2012). Learning Theories an Education Perspective. Yogyakarta: Pustaka Pelajar.

Tejakusuma, I. G. (2005). Analisis Pasca Tsunami Aceh. Jurnal Alami. 10(2).

Vassala, P. (2006). The Field Study As An Educational Technique In Open and Distance Learning. Turkish Online Journal of Distance Education. 7(4). ISSN-1302-6488. 